\title{
The Development and Characterisation of Aluminium Dross-Epoxy Resin Composite Materials
}

\author{
Agunsoye J. O. ${ }^{1}$, Talabi S. I. ${ }^{2}$, Hassan S. B. ${ }^{1}$, Awe I. O. ${ }^{3}$, Bello S. A. ${ }^{1}$ \& Aziakpono E. ${ }^{1}$ \\ ${ }^{1}$ Department of Metallurgical and Materials Engineering, University of Lagos, Akoka, Nigeria \\ ${ }^{2}$ Department of Materials and Metallurgical Engineering, University of Ilorin, Ilorin, Nigeria \\ ${ }^{3}$ Department of Metallurgical Engineering, Yaba College of Technology, Yaba, Lagos, Nigeria \\ Correspondence: Agunsoye J. O., Department of Metallurgical and Materials Engineering, University of Lagos, \\ Akoka, Lagos State, Nigeria. Tel: 234-808-302-1146. E-mail: jagunsoye@unilag.edu.ng
}

Received: November 18, 2013 Accepted: January 6, 2014 Online Published: February 8, 2014

doi:10.5539/jmsr.v3n2p23

URL: http://dx.doi.org/10.5539/jmsr.v3n2p23

\begin{abstract}
The effects of aluminium dross filler on the wear behaviour and thermal stability of epoxy resin (ER) system were investigated. The microstructure of the samples was examined with aids of scanning electron microscope (SEM) to explain the basis for the observed changes in the epoxy resin due to the filler additions. A carbon steel die mould was used for casting the aluminium dross-epoxy resin composites. SEM, X-ray Diffractometer (XRD), Thermogravimetric Analyser (TGA) and spin on disc machine was used to characterise the microstructure, composition, thermal stability and wear behaviour under dry lubrication conditions of the developed composites. The study showed that additions of particulate aluminium dross significantly improved the thermal and wear resistance of the developed composite. The wear resistance increased as the speed and applied load increased. The improved thermal stability is attributable to the presence of new phase (refractory oxide and carbide). The aluminium dross-epoxy resin composite is an excellent material in an application requiring low, tensile strength, low wear resistance and moderate thermal resistance especially in the handle for domestic cooking pot; spoon; screw driver and protecting case for electric iron, television and radio.
\end{abstract}

Keywords: refractoriness, thermogravimetric analysis, wear resistance, reinforcer, aluminium dross

\section{Introduction}

Industries have primarily had to face the problem of fully obtaining the performance benefits of composite materials at lowered production costs (Stickler, 2002; Miller, 2007). In some cases, composites materials have been an expensive alternative to the use of aluminium materials. Consequently, composite technology research and development efforts have been focused on means of producing low-cost composite products. Epoxy resins (EPs) which are considered to be one of the most important classes of thermosetting polymers is a good candidate to solving this challenge if it can be reinforced with low-cost filler. Epoxy resins have good mechanical and thermal properties, high chemical and corrosion resistance, low shrinkage on curing and the ability to be processed under a variety of conditions. In the past, researchers have examined the preparation and characterization of epoxy resins using a range of inorganic fillers. Inorganic fillers were added to the epoxy system to optimize its thermal stability, glass transition temperature, and dimensional stability (Tarrío-Saavedra et al., 2008; Kuan et al., 2010). It has been shown by researchers that particulate fillers improved the Young Modulus (Rosso et al., 2006; Milad et al., 2013) and strength (Brunner et al., 2006) when the particles are well bonded to the matrix. However, for poorly bonded micro-particles, strength reductions occur by adding the particles (Tjong \& Zhu, 2000; Liang et al., 1997). Although they do not improve the fracture toughness of the epoxy system compared to rubber, inorganic particles have also been found to be effective toughner for epoxy resins. Also, they increase the elastic modulus and hardness much better than rubber particles.

Aluminium dross addition has been found to improve the ultimate tensile strength of the polyethylene by $68 \%$ at $15 \% \mathrm{wt}$ of addition while the aluminium dross addition at the same composition has no effect on the impact resistance of the matrix (Adeosun et al., 2012).

In this research epoxy resin was reinforced with aluminium dross (waste) to produce a novel epoxy resin composite at a low overall total cost. 


\section{Materials and Methodology}

Epoxy resin of the type (LY 556) was used as the main matrix with aluminium dross as a reinforcer (Figure 1). The chemical composition of aluminium dross is shown in Table 1.

Table 1. Analysis of the composition of aluminium dross

\begin{tabular}{lccccccccc}
\hline $\begin{array}{l}\text { Elemental } \\
\text { Spec }\end{array}$ & $\mathrm{SiO}_{2}$ & $\mathrm{CaO}$ & $\mathrm{Na}_{2} \mathrm{O}$ & $\mathrm{Al}_{2} \mathrm{O}_{3}$ & $\mathrm{Fe}_{2} \mathrm{O}_{3}$ & $\mathrm{MgO}$ & $\mathrm{SO}_{3}$ & $\mathrm{~K}_{2} \mathrm{O}$ & $\mathrm{Al}$ \\
$\begin{array}{l}\text { Percentage } \\
\text { (wt) }\end{array}$ & 7.14 & 0.09 & 0.05 & 63.88 & 0.02 & 0.04 & 0.02 & 0.02 & 28.74 \\
\hline
\end{tabular}

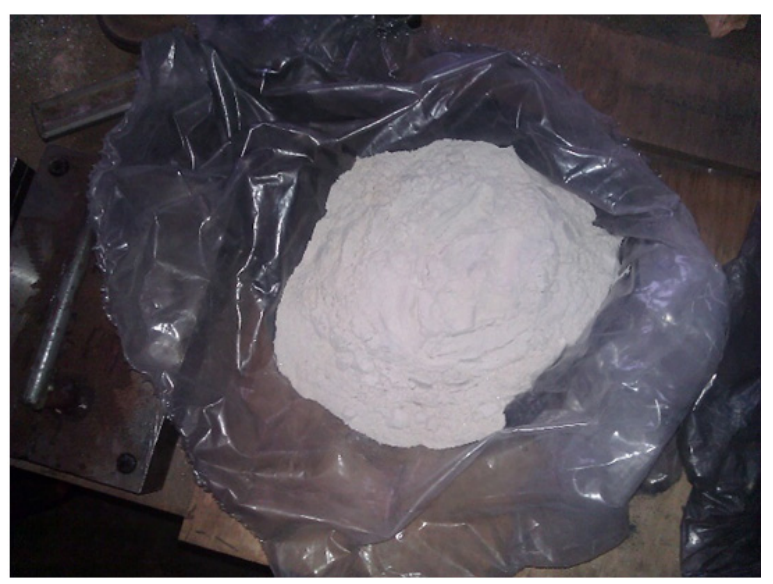

Figure 1. Sieved aluminium dross particulates

\subsection{Methods}

A mixture of 5\%wt aluminium dross and $95 \%$ wt epoxy resin (LY 556) were mixed and mechanically stirred vigorously for 4 minutes with a glass rod inside a $500 \mathrm{~cm}^{3}$ material. The mixture was cast into a carbon steel die mould of two halves with locating pins for proper alignment (Figure 2). The aluminium dross-epoxy resin mixture was left for 24 hours in the mould for curing (Figure 3) after which the aluminium dross-epoxy resin composite was stripped out of the mould. The same procedures were repeated for the remaining aluminium dross-epoxy resin composite blends with the following compositions of $10 ; 15$ and $20 \%$ aluminium dross filler additions. Samples of the as-cast aluminium dross-epoxy resin composites are presented in Figure 4.

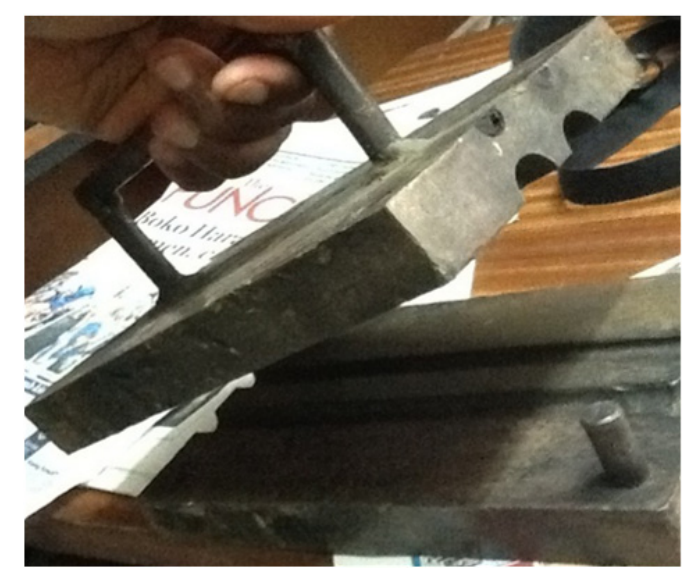

Figure 2. A medium carbon steel die mould with improvised cavity 


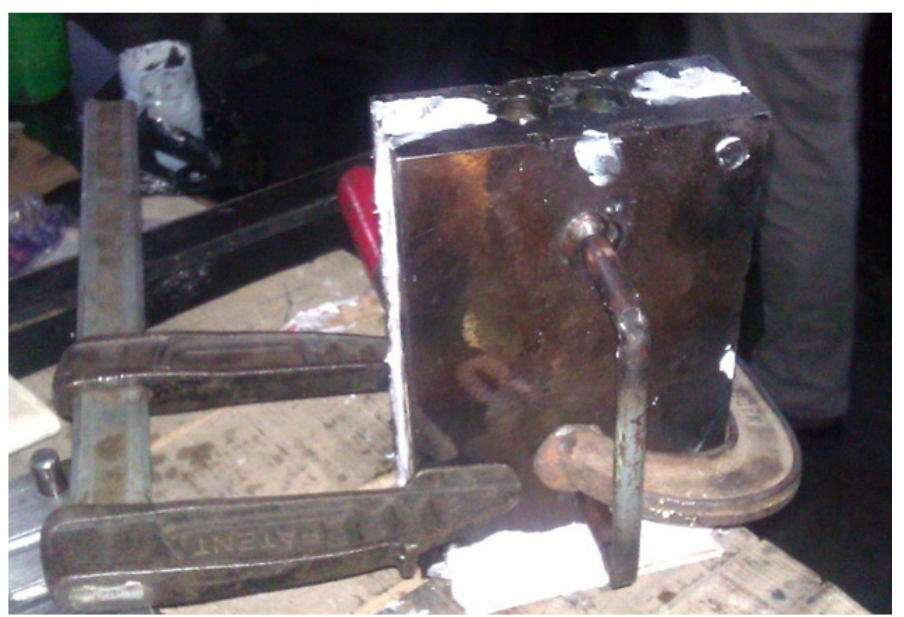

Figure 3. Curing of the aluminium dross-epoxy resincomposite sample

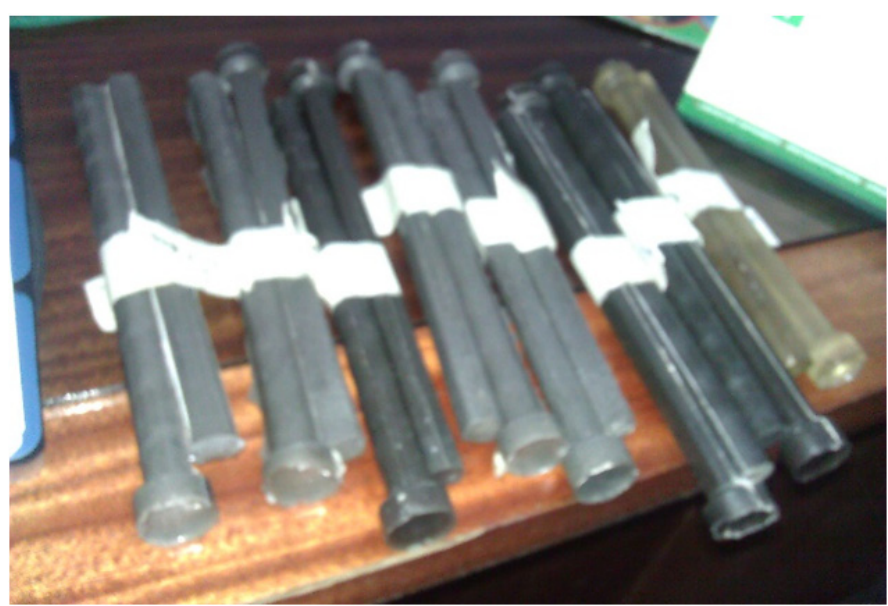

Figure 4. Cast epoxy resin/aluminium dross samples

Each sample of the aluminium dross-epoxy resin composites was prepared into different coupons for XRD, microstructural analysis, TGA, and wear tests.

Representative sample coupon of aluminium dross-epoxy resin composite were subjected to XRD analysis to examine the distribution of the phases present in the developed epoxy resin composite matrix with their corresponding count scores and chemical compound formulae.

The morphology of the phases present in the matrix of the aluminium dross-epoxy resin composites, and epoxy resin control sample were examined using Scanning Electron Microscope model EVOMA 10 LaB6 Analytical VP-SEM at $20 \mathrm{KV}$.

The oxidation characteristics and thermal stability of the control sample and the developed aluminium dross-epoxy resin composite were analysed alongside the temperature transition with the aids of TGA 701 at a heating rate of $10^{\circ} \mathrm{C} / \mathrm{min}$ starting from room temperature to the temperature at which the weight of the sample remained constant $\left(900{ }^{\circ} \mathrm{C}\right)$. The TGA analysis for the developed composites was performed in an oxidising environment with a linear temperature ramp. The samples were heated from room temperature $\left(30^{\circ} \mathrm{C}\right)$ to a maximum temperature, $900{ }^{\circ} \mathrm{C}$ until the weight of the samples remained unchanged. The maximum temperature is the temperature attained when the oxidation reaction has been completed (all the polymeric molecules have been burnt off leaving behind non-volatile oxides).

This method gives three important numerical pieces of information which are weight loss, heating time and oxidation temperature. Oxidation temperature includes onset oxidation temperature $\left(T_{\text {on }}\right)$ and maximum oxidation temperature $\left(T_{0}\right)$. The latter is the temperature at which the oxidation rate is maximum i.e. where the weight loss is maximum and the former corresponds to the temperature when the oxidation of the polymeric 
material just begins. It is very difficult to determine the $T_{\text {on }}$ accurately due to resistance of material to thermal application.

The wear behaviour of the developed aluminium dross-epoxy resin composite was studied with the aids of pin on disc machine. The wear test was carried out on a $200 \mathrm{~mm}$ circular rotating disc with attached emery paper of 180 grit size. The weight difference before and after the wear test were measured in grammes with the aids of digital electronic scale. The surface of the test sample was placed against the rotating disc for a period of $60 \mathrm{~s}$ under different applied loads and speed. The experiment was repeated four times and the weight loss at each instance was calculated using Equation 1. Equation 4 was used to calculate the wear coefficients.

$$
\text { Weight loss }(w l)=\text { initial weight }- \text { final weight }
$$

The volume loss for each sample of experiments was calculated using Equation 2

$$
\text { Volume loss }=\frac{w l}{\rho}
$$

Sliding distance and moment were calculated using Equations 3 and 4 respectively

$$
\begin{gathered}
\text { Sliding distance }=\text { sliding Speed } x \text { time } \\
\text { Sliding moment }=\text { Applied load } x \text { sliding distance }
\end{gathered}
$$

The wear coefficient of each sample was calculated using Equation 5

$$
\text { Wear coefficient }=\frac{\text { Volume loss }(\mathrm{Vl})}{\text { Sliding moment }(\mathrm{M})}
$$

\section{Results and Discussion}

\subsection{XRD Compositional Analysis}

Figures 5-7 show the diffraction pattern of spots or reflection reported on a screen of a laser pointer when aluminium dross and aluminium dross-epoxy resin composite was analysed with the aids of X-ray diffractometer.

Figure 5 shows the presences of aluminium manganese titanium, burnt lime, pyrolusite, phosphorus oxide and sodium aluminium sulphide in the aluminium dross. The count scores of the compounds with their corresponding compound formulae are also presented in Table 2.

Figures 6 and 7 show the X-ray diffractometer results for the aluminium dross-epoxy resin composites, indicating the distribution of phases present within the matrix of the developed composites. The chemical formulae and the count score of the compounds are presented in Tables 3 and 4 respectively.

From Tables 3 and 4, it was observed that there are formation of new phases (quarts, silicon oxide and titanium hydride, potassium silicon, pyrites, iron manganese silicon) due to interaction of aluminium dross and the epoxy resin. This may be attributable to the exothermic reaction during the mixing and curing processes. Furthermore, it was observed that the level of segregation of the following intermetallic compounds aluminium manganese titanium, iron manganese silicon, aluminium oxide is pronounced. Also, silicon carbide (moissanite) and iron sulphide and iron oxide are at peaks (Figures 6 and 7). 


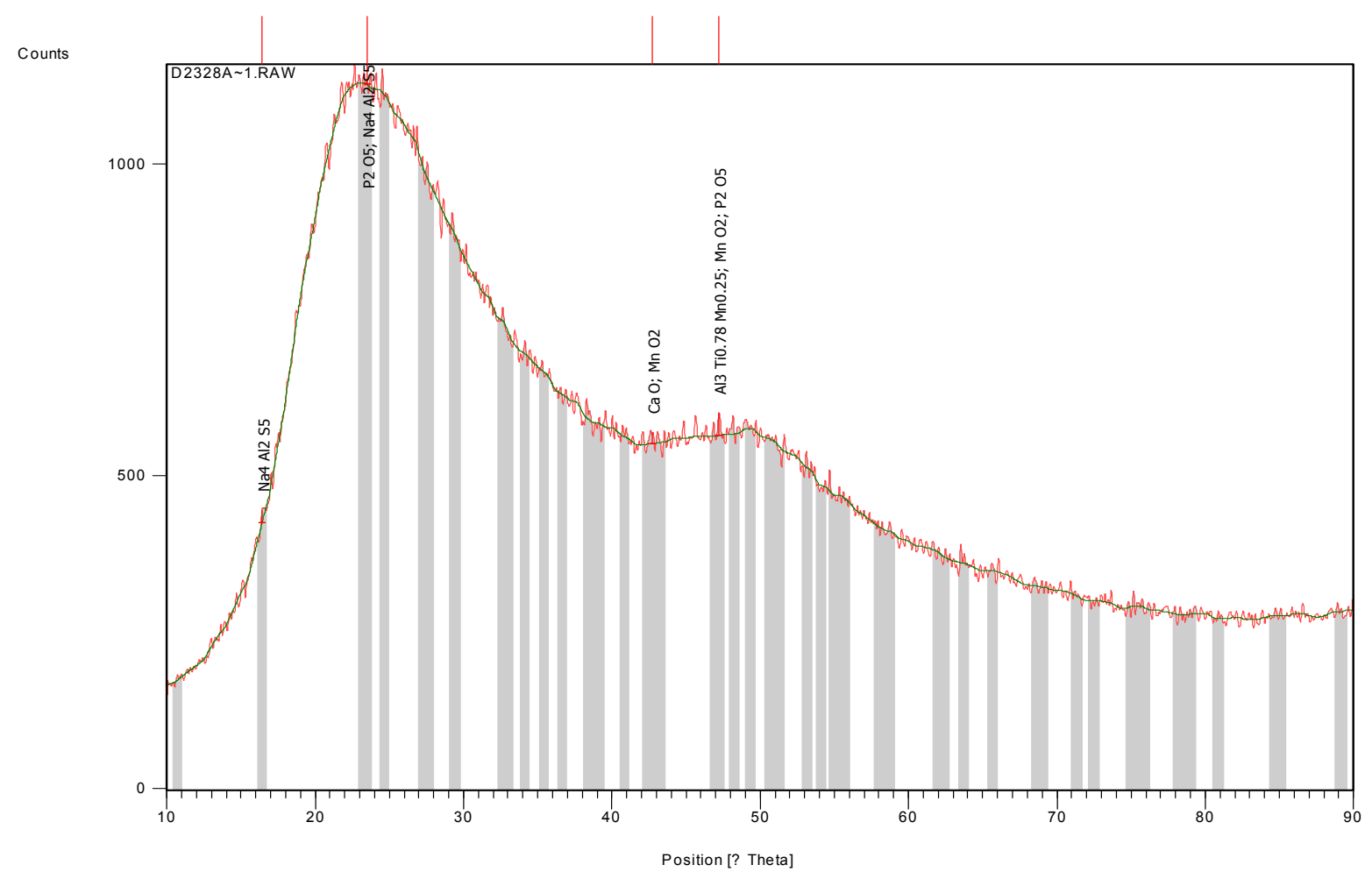

Figure 5. XRD compositional analysis of the epoxy resin (control sample)

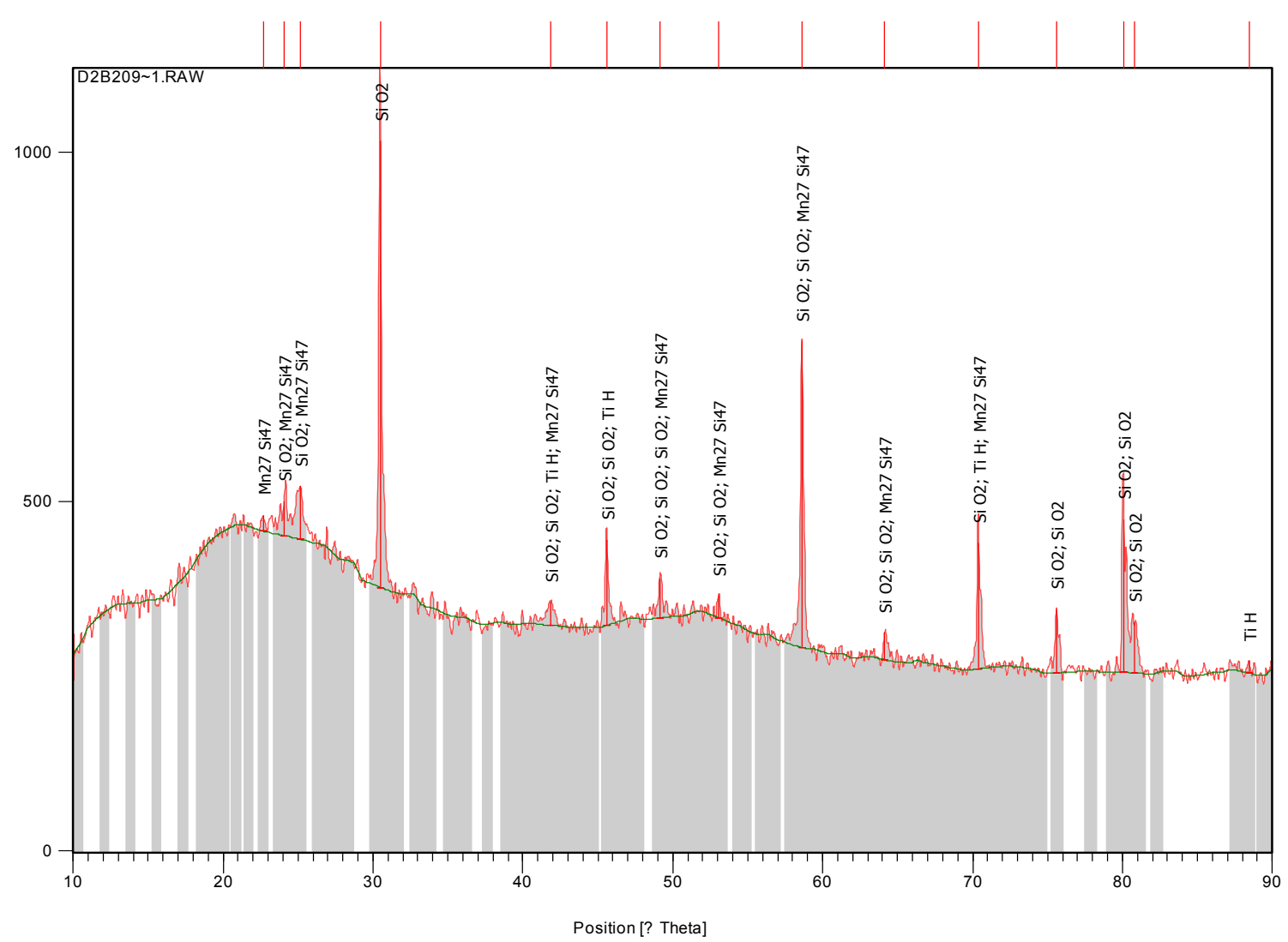

Figure 6. XRD compositional analysis of ER-5\%Al dross composite 
Table 2. Count scores and chemical formulae of identified compounds present in the matrix of the epoxy resin

\begin{tabular}{lll}
\hline Score & Compound Name & Chemical Formula \\
\hline 54 & Aluminium Manganese Titanium & $\mathrm{Al}_{3} \mathrm{Ti}_{0.78} \mathrm{Mn}_{0.25}$ \\
37 & burnt lime & $\mathrm{CaO}$ \\
17 & Pyrolusite & $\mathrm{MnO}_{2}$ \\
8 & Phosphorus Oxide & $\mathrm{P}_{2} \mathrm{O}_{5}$ \\
12 & Sodium Aluminium Sulfide & $\mathrm{Na}_{4} \mathrm{Al}_{2} \mathrm{~S}_{5}$ \\
\hline
\end{tabular}

Table 3. Count score and chemical formulae of the identified compounds in the matrix of ER-5\%Al dross composite

\begin{tabular}{lll}
\hline Score & Compound Name & Chemical Formula \\
\hline 56 & Quartz \$GA, syn & $\mathrm{SiO}_{2}$ \\
74 & Silicon Oxide & $\mathrm{SiO}_{2}$ \\
24 & Titanium Hydride & $\mathrm{TiH}$ \\
12 & Manganese Silicon & $\mathrm{Mn}_{27} \mathrm{Si}_{47}$ \\
\hline
\end{tabular}

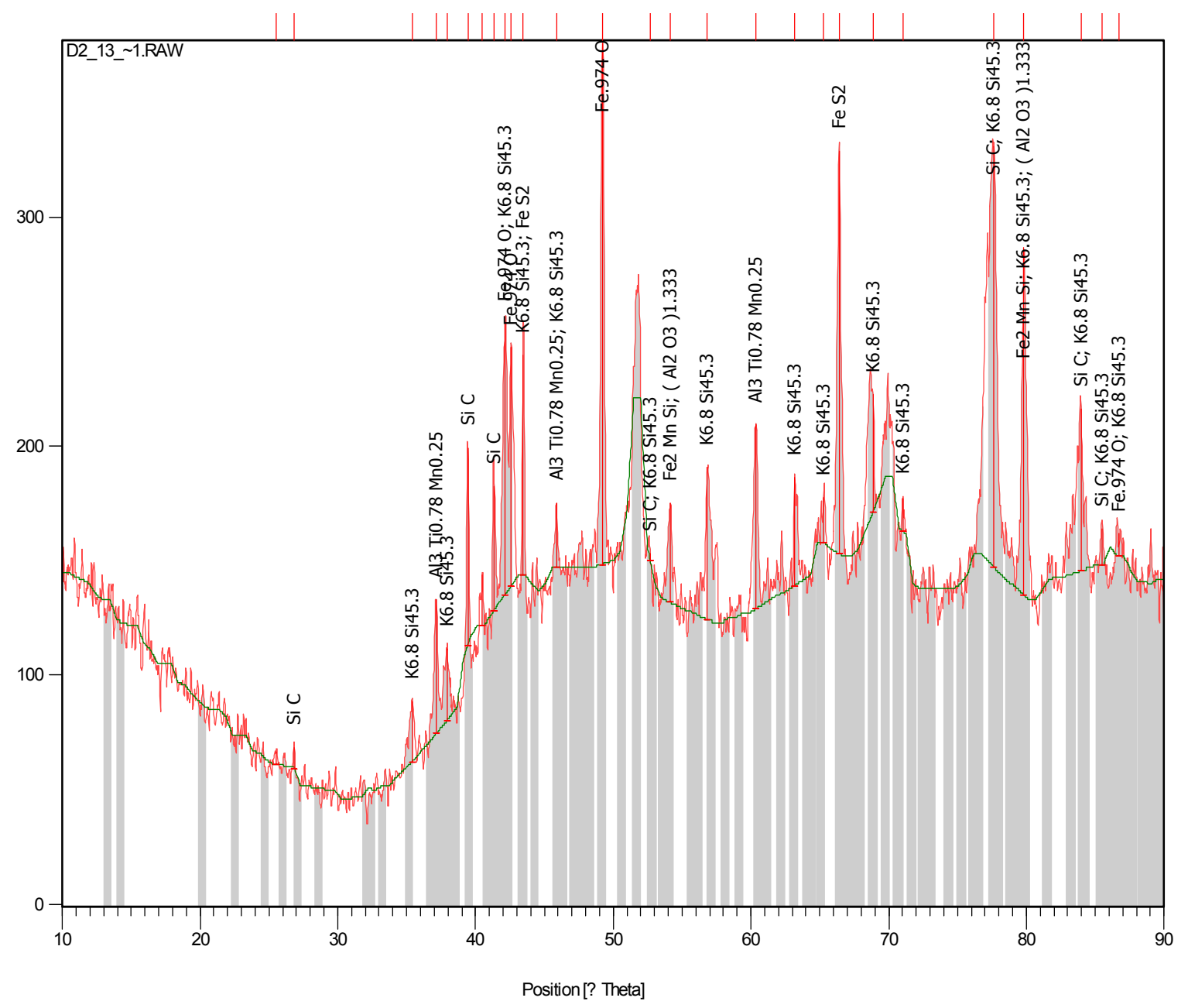

Figure 7. The XRD phase compositional analysis of ER-20\%Al dross composite 
Table 4. Count score and formulae of identified phases in the matrix of ER-20\%Al dross composite

\begin{tabular}{lll}
\hline Score & Compound Name & Chemical Formula \\
\hline 34 & Aluminium Manganese Titanium & $\mathrm{Al}_{3} \mathrm{Ti}_{0.78} \mathrm{Mn}_{0.25}$ \\
34 & Iron Manganese Silicon & $\mathrm{Fe}_{2} \mathrm{MnSi}$ \\
28 & Iron Oxide & $\mathrm{Fe}_{97.4} \mathrm{O}$ \\
23 & Moissanite 6\TH $\backslash R \mathrm{R}$ & $\mathrm{SiC}$ \\
18 & Potassium Silicon & $\mathrm{K}_{6.8} \mathrm{Si}_{45.3}$ \\
13 & Pyrites & $\mathrm{FeS}_{2}$ \\
32 & Aluminium Oxide & $\left(\mathrm{Al}_{2} \mathrm{O}_{3}\right) 1.333$ \\
\hline
\end{tabular}

\subsection{Microstructural Analysis}

Figure 8 represents the SEM micrograph of the epoxy resin (control sample). It can be seen that the microstructure is fairly homogenous when compared with that of the developed composites because of the absence of the second phase particles.

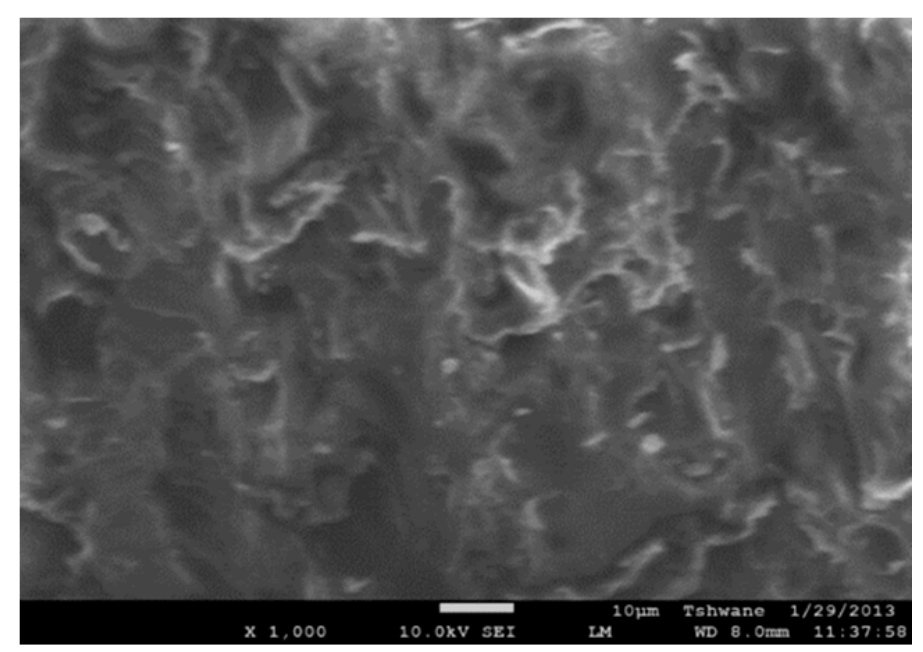

Figure 8 . SEM micrograph of epoxy resin $(\times 1000)$

Figures 9 and 10 represents the SEM micrographs of ER-5\%Al dross and ER-20\% Al dross composites. The matrix of composite contains the new phases such as quarts, silicon oxide and titanium hydride respectively. The silicon oxide is the most dominant phase in Figure 9 and silicon carbide in Figure 10. They are represented by black polygonal shapes as depicted by $\mathrm{H}$ in Figure 9 and $\mathrm{M}$ in Figure 10 respectively. The white patches area represented by $\mathrm{W}$ is the titanium hydride. The presence of titanium hydride and silicon oxide in the composite is beneficial in improving on the thermal stability of the developed composite due to their high refractory properties. 


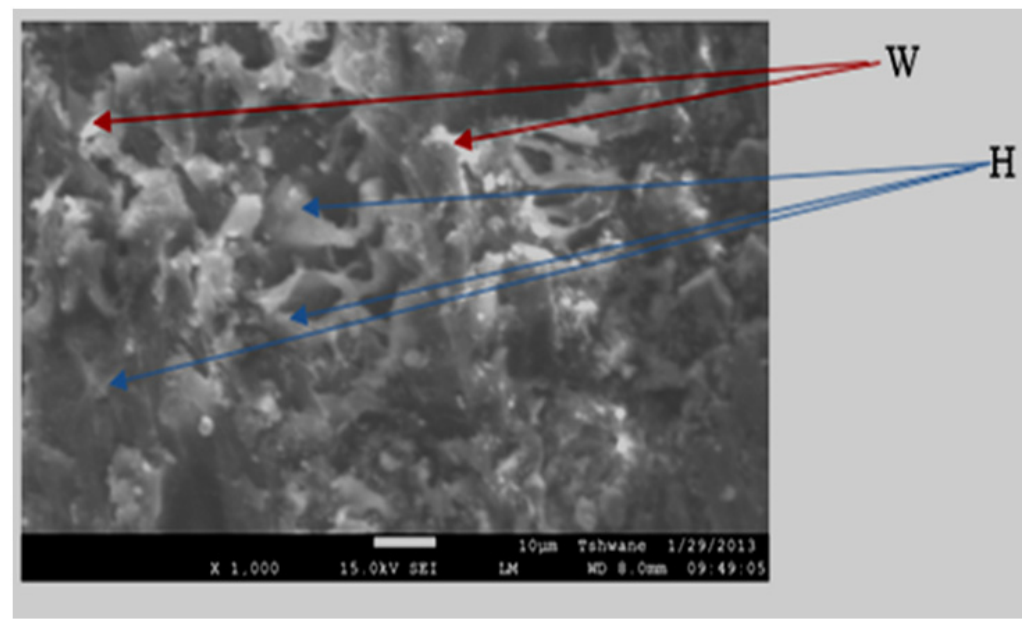

Figure 9. SEM micrograph of ER-5\%Al dross composite $(\times 1000)$

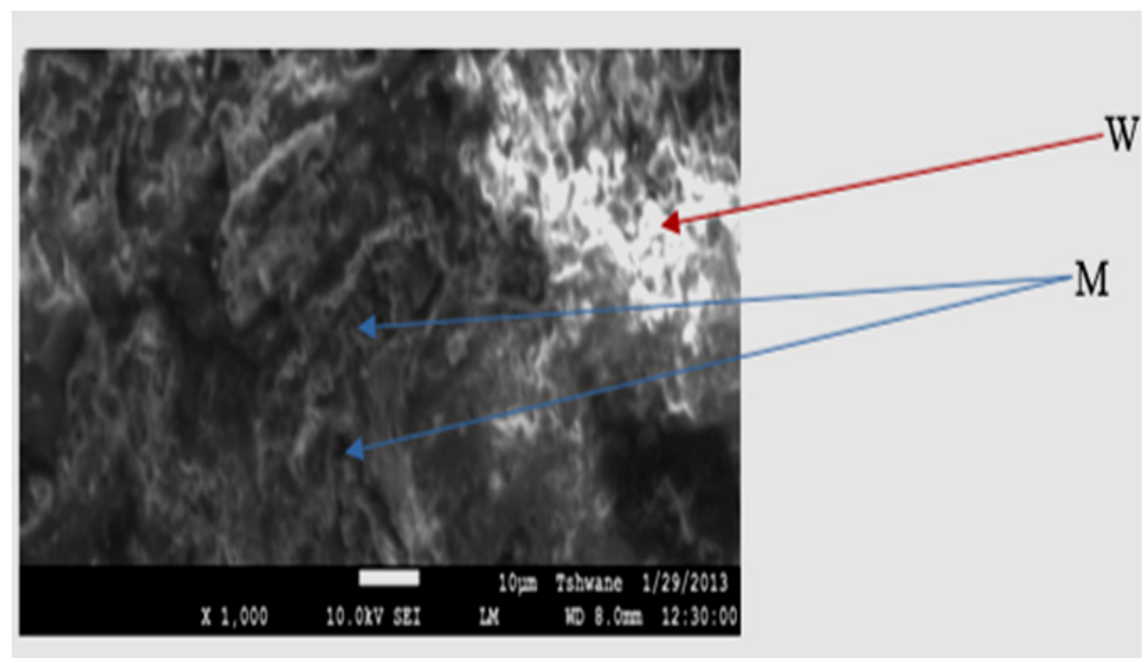

Figure 10. SEM micrograph of ER-20\%Al dross composite $(\times 1000)$

\subsection{Thermogravimetric Analysis}

The thermogravimetric analysis of the epoxy resin control sample and aluminium dross-epoxy resin (ER-Al dross) composites were studied as a function of weight loss as temperature and time increased (Figures 11-14).

The resistance to thermal application at initial stage is attributed to the presence of aluminium dross particles in the reinforced epoxy resin composites because of the refractoriness of the fillers.

For the epoxy resin, degradation of the resin began in the temperature range of $100-150{ }^{\circ} \mathrm{C}$ corresponding to time interval between 40 and $45 \mathrm{~min}$ and is accompanied with breakage of $\mathrm{C}-\mathrm{C}, \mathrm{CO}, \mathrm{C}-\mathrm{H}$ and $\mathrm{OH}$ bonds of the resin while the initial and final decomposition temperatures (IDT and FDT) are 250 and $320{ }^{\circ} \mathrm{C}$ respectively (Figure 11). 


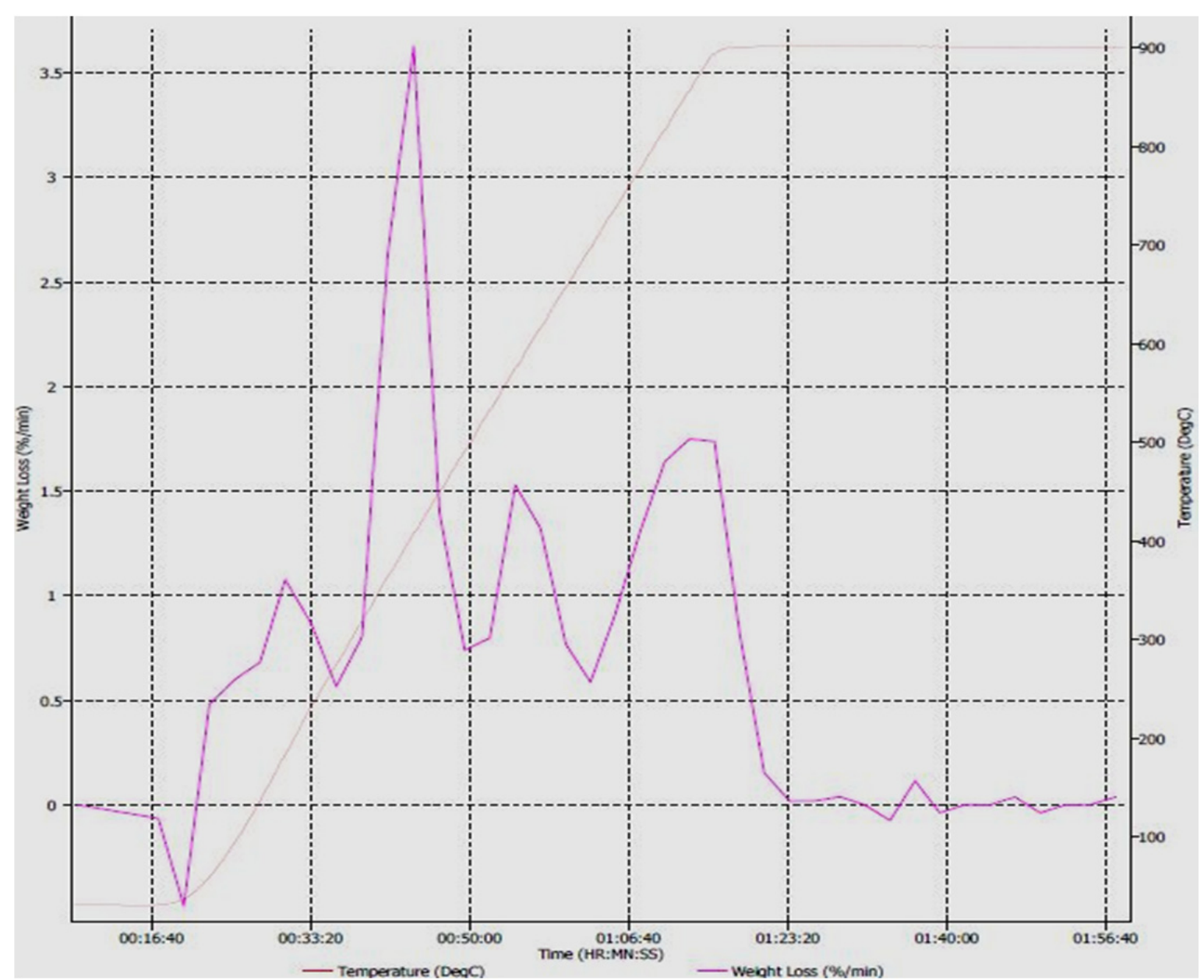

Figure 11. TGA of the epoxy resin of the control sample

In the case of the developed epoxy resin - $\mathrm{Al}$ dross composites, initial decomposition temperature ranges from $250-320^{\circ} \mathrm{C}$ and final decomposition temperature range from 360 to $460{ }^{\circ} \mathrm{C}$ respectively (see Figures $12-14$ ).

The increase in the values of the initial and final decomposition temperatures of the aluminium dross-epoxy resin composites is attributed to the presence of the aluminium dross which is a refractory material in the matrix of the developed composites. The developed composites are able to withstand higher temperature than the epoxy resin (control) addition without aluminium dross. The more the number of peaks, the more the presence of second phase particles with higher refractory property in the matrix. Overall, the choice of aluminium dross as filler improved the thermal characteristics of epoxy resin and is in agreement with the findings of other authors (Ruban et al., 2013; Reddy et al., 2006). 


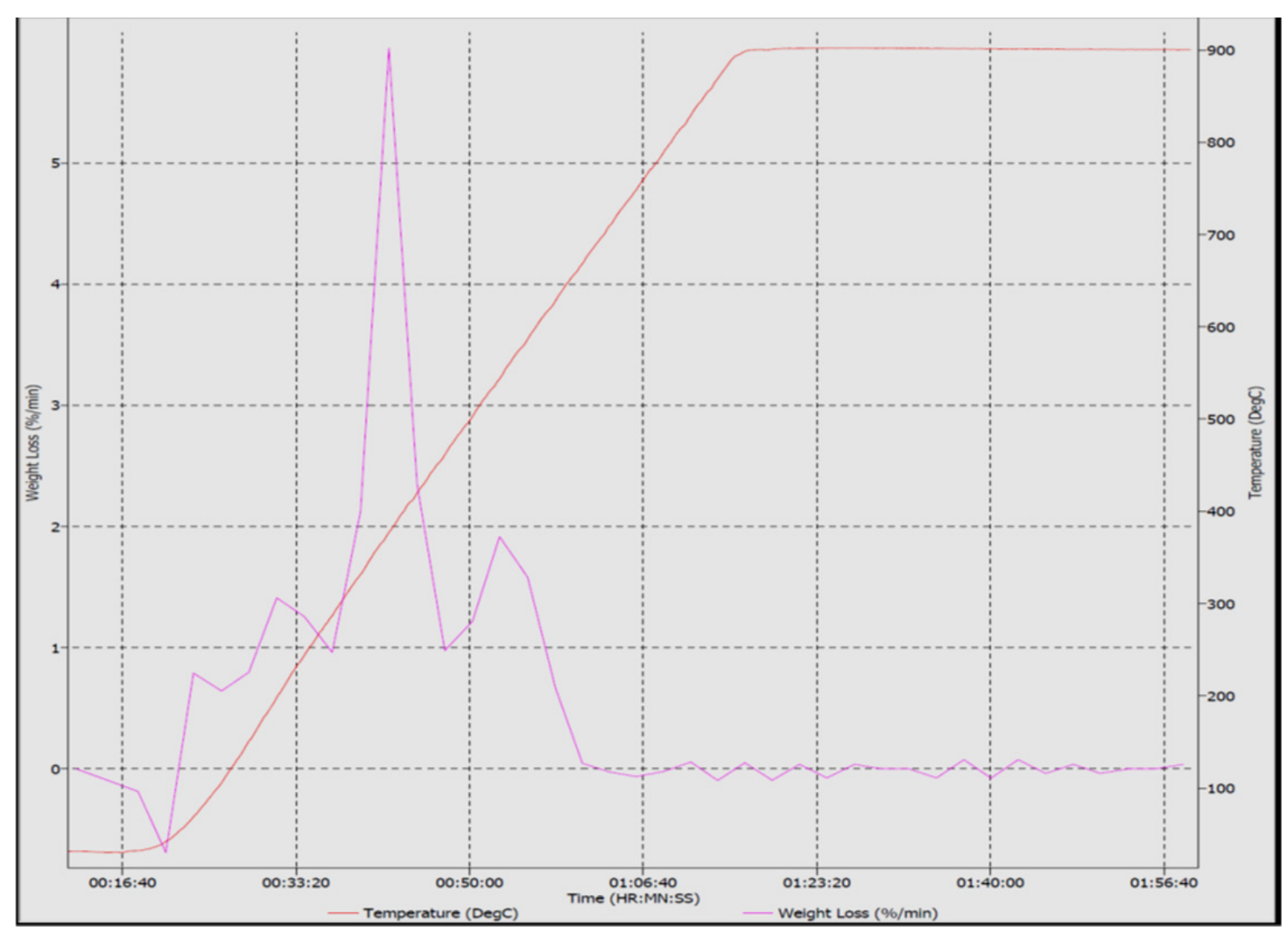

Figure 12. TGA of the ER-5\%Al dross composite

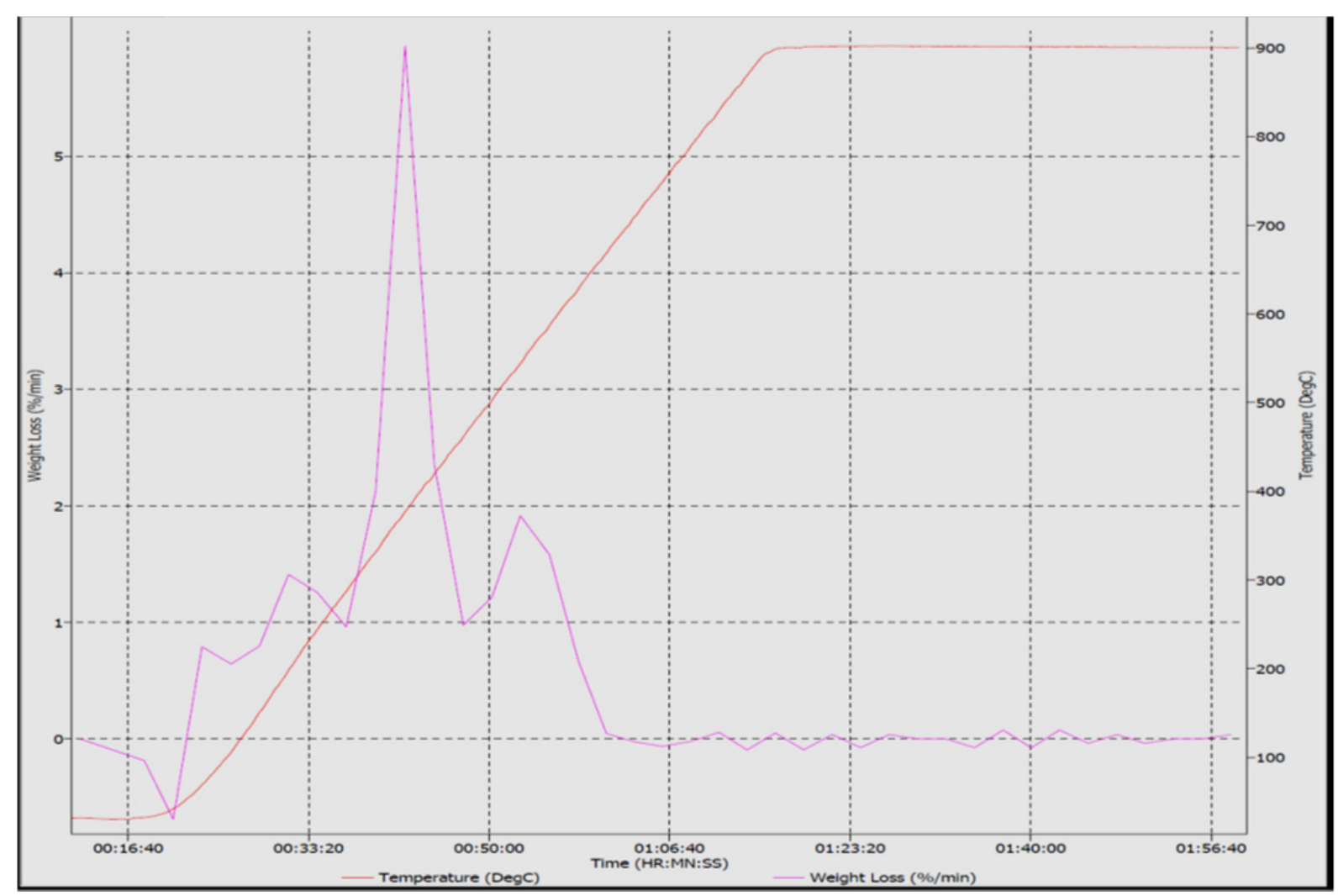

Figure 13. TGA of the ER-15\%Al dross composite 


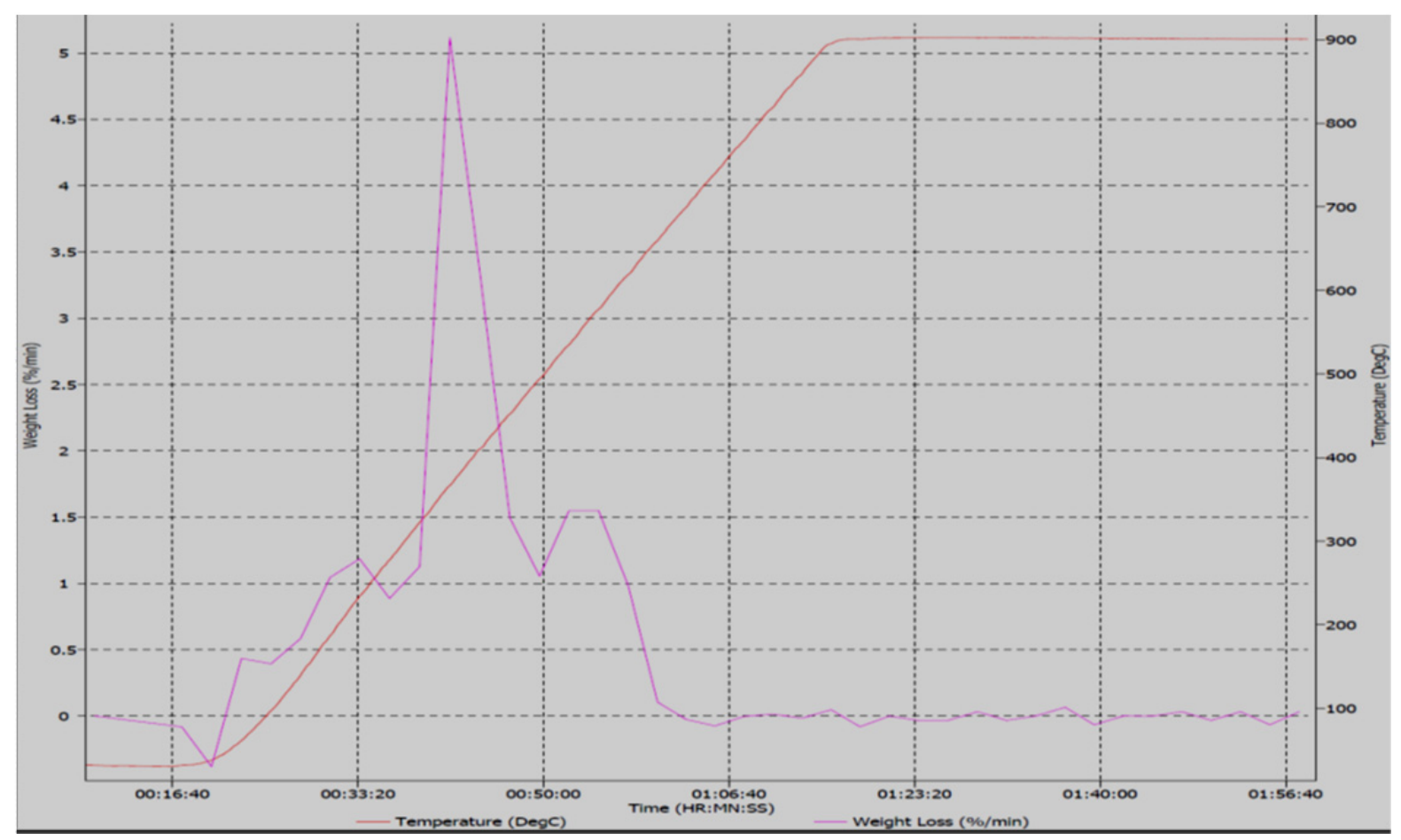

Figure 14. TGA of the ER-20\%Al dross composite

\subsection{Wear Analysis}

Figures 15-20 show the relationship between wear coefficient and time from the wear analysis carried out on the control sample (epoxy resin) and the developed aluminium dross-epoxy resin composite under different loads and speed. Generally, it was observed that the wear coefficient decreased as the time and speed increased at different applied loads from 6 to $16 \mathrm{~N}$. The wear coefficient is the indicator for measuring wear resistance. The higher it is the lower is the wear resistance as the percentage of aluminium dross addition increased. Hence, the observed increase in the wear resistance of the developed ER-Al dross composite (Kanchanomai et al., 2011; Yingke et al., 2012; Ayman et al., 2012). This may be attributable to the higher packing density of the aluminium dross (filler) addition (Bum-Soon et al., 2008).

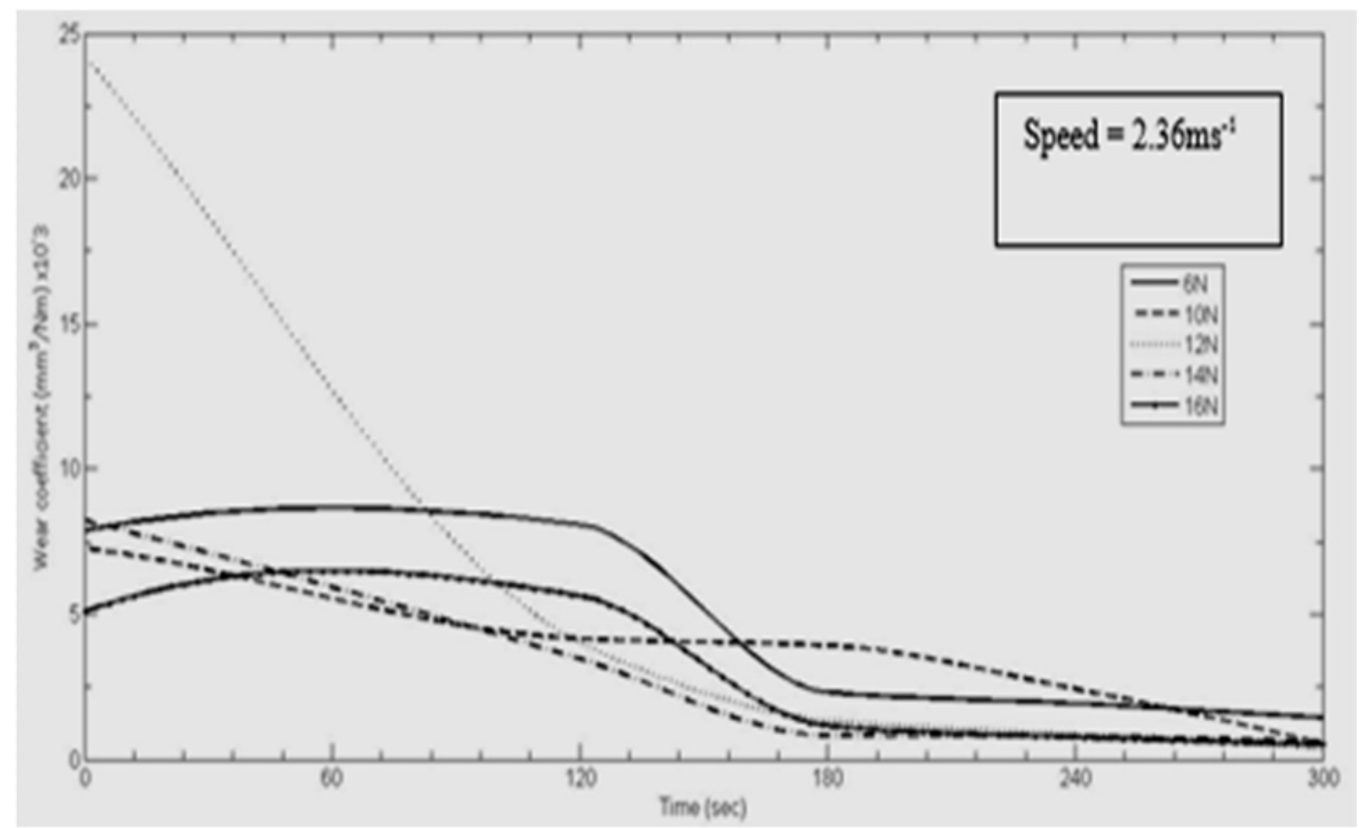

Figure 15. Wear coefficient of epoxy resin (control sample) with time at $2.36 \mathrm{~ms}^{-1}$ 


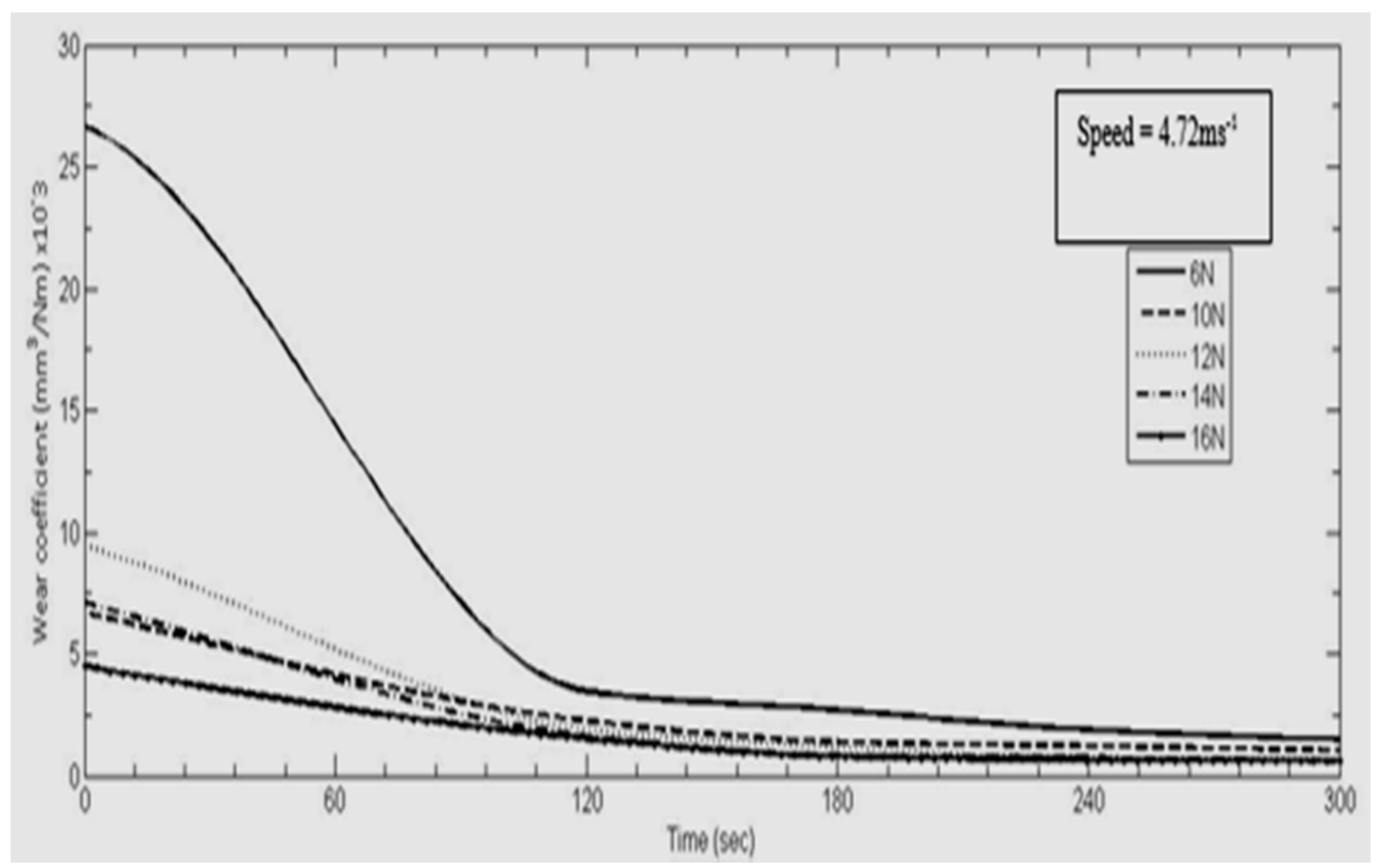

Figure 16. Wear coefficient of epoxy resin (control sample) with time at $4.72 \mathrm{~ms}^{-1}$

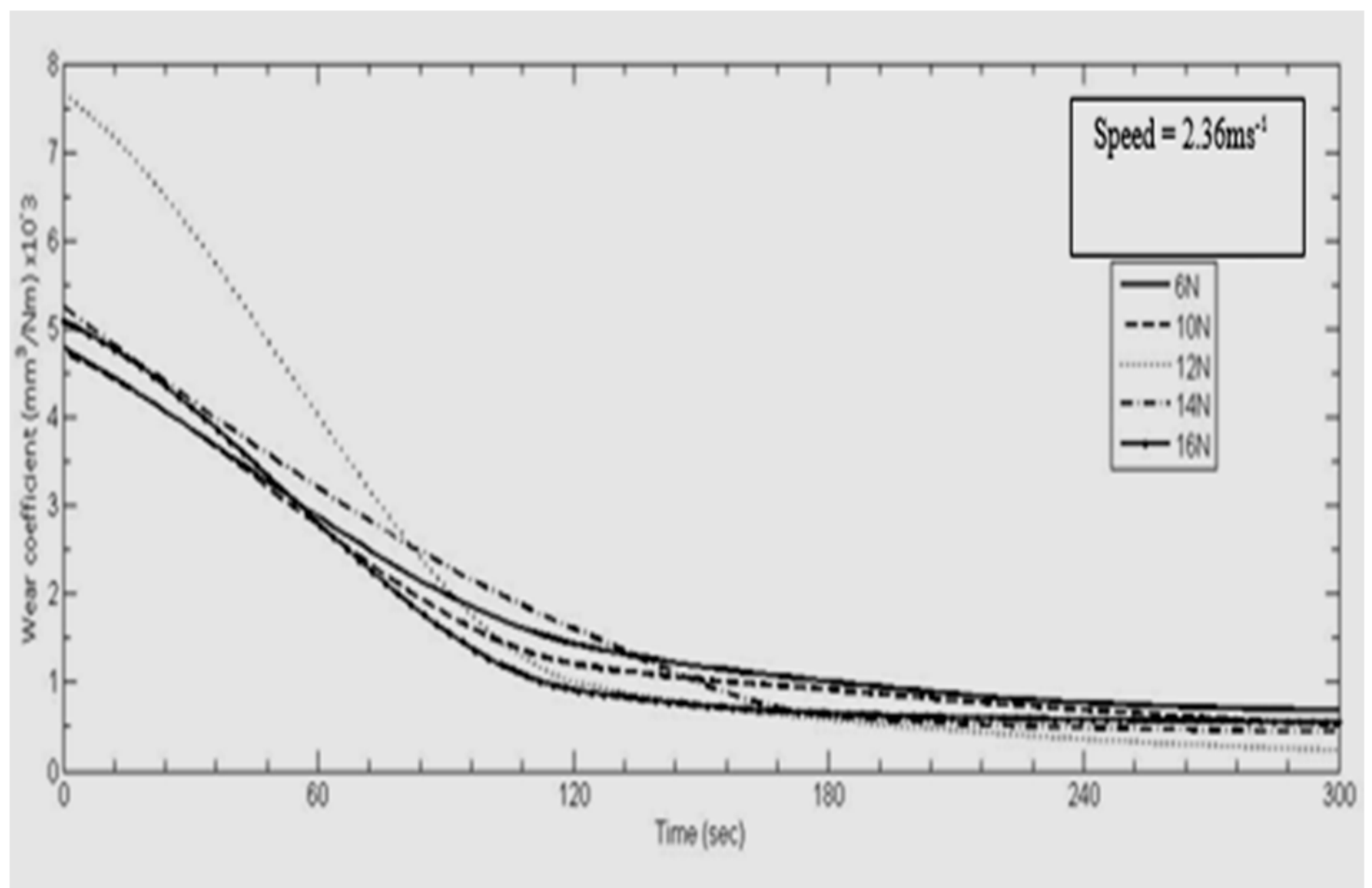

Figure 17. Wear coefficient of the ER-5\%Al dross composite with time at $2.36 \mathrm{~ms}^{-1}$ 


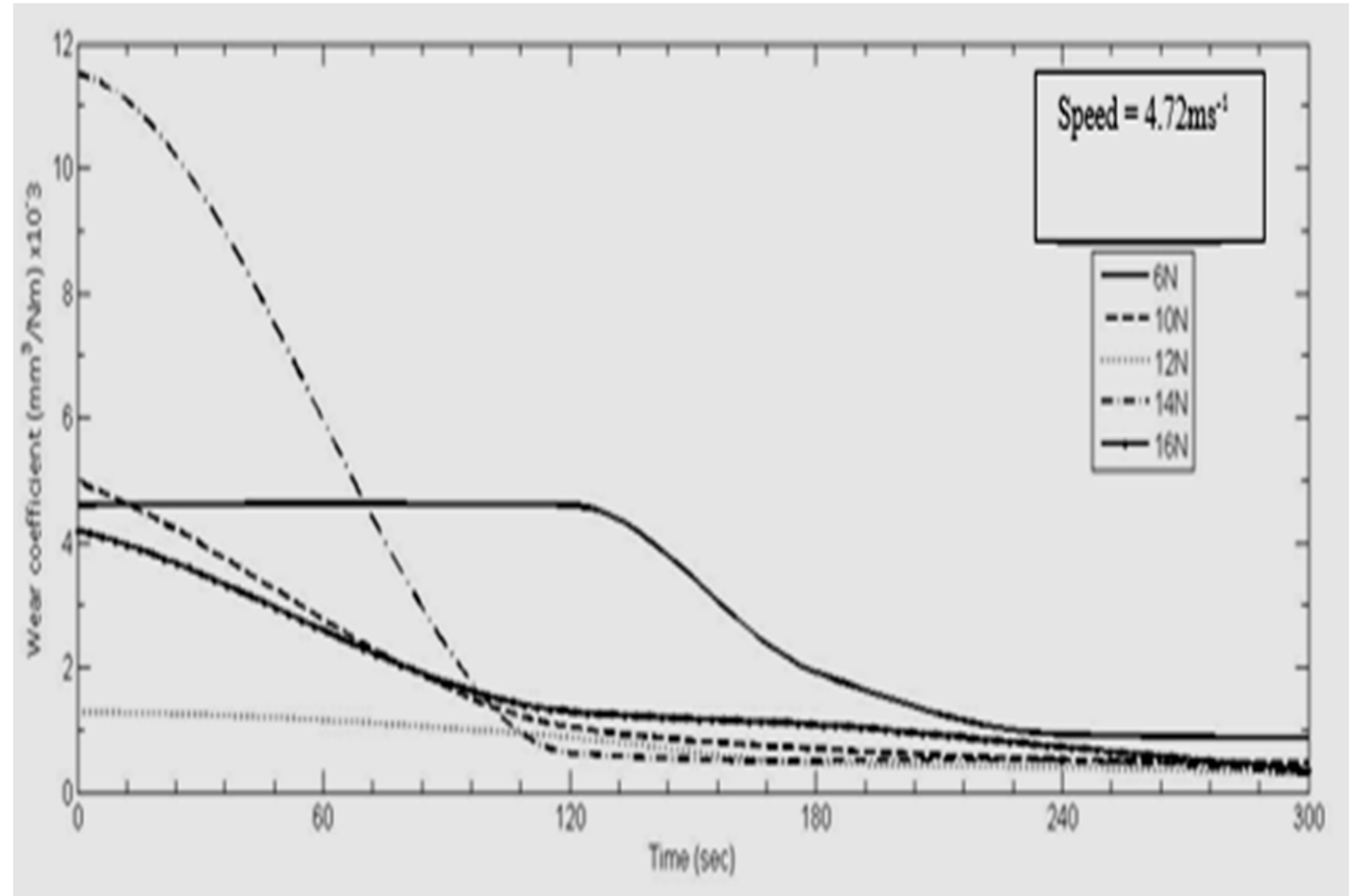

Figure 18. Wear coefficient of the ER-5\%Al dross composite with time at $4.72 \mathrm{~ms}^{-1}$

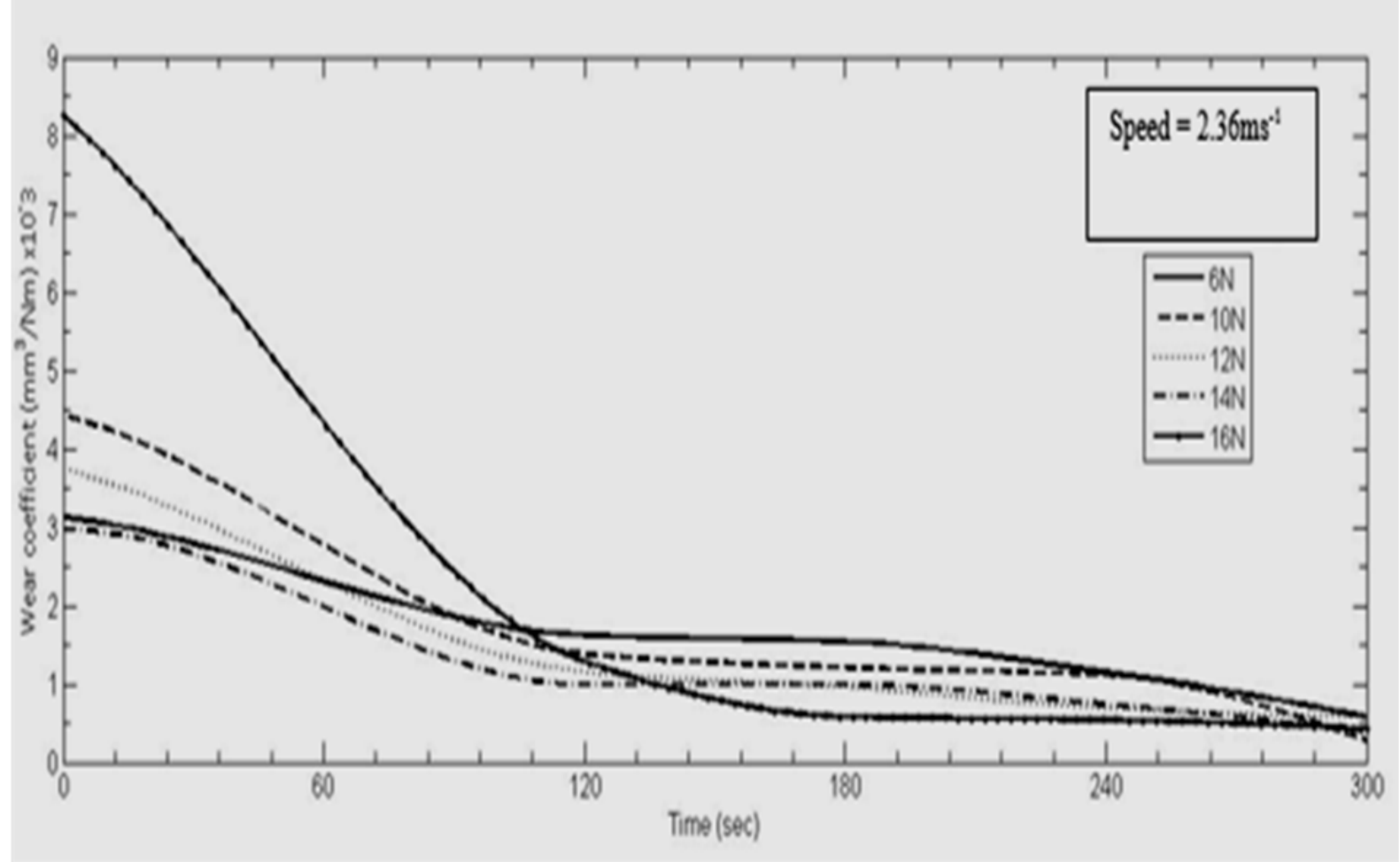

Figure 19. Wear coefficient of the ER-20\%Al dross composite with time at $2.36 \mathrm{~ms}^{-1}$ 


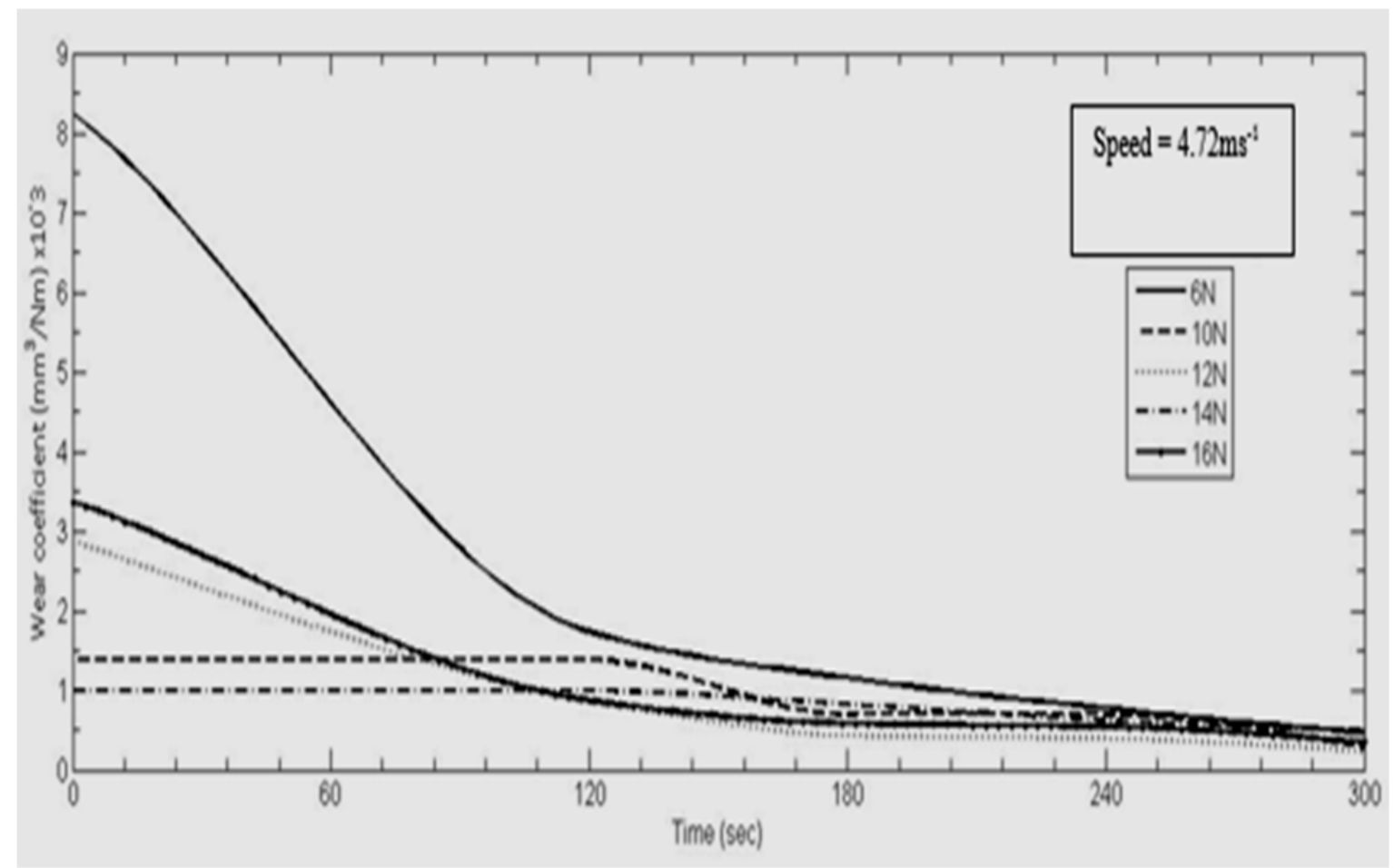

Figure 20. Wear coefficient of the ER-20\%Al dross composite with time at $4.72 \mathrm{~ms}^{-1}$

\section{Conclusion}

Based on the results and discussion of this work, the following conclusion can be made:

1) Addition of aluminium dross improves the wear resistance of the epoxy resin composites. This is agreed with other related work on particle reinforced composite. This may be attributable to the higher packing density of the aluminium dross (filler) addition.

2) Addition of the aluminium dross to the epoxy resin improved the thermal stability of the developed composite $32 \%$. The developed composites are able to withstand higher temperature than the epoxy resin (control) addition without aluminium dross. The increase in the values of the initial and final decomposition temperatures of the aluminium dross-epoxy resin composites is attributed to the presence of the aluminium dross which is a refractory material in the matrix of the developed composites.

3) New phases such as quarts, silicon oxide and titanium hydride are formed due chemical reaction of the epoxy resin and constituent element in the Al-dross. The silicon oxide is the most dominant phase.

4) It was observed that the level of segregation of the following intermetallic compounds aluminium manganese titanium, iron manganese silicon, aluminium oxide is pronounced.

5) Overall, the enhancement in the composites thermal and wear resistance is attributable to the newly formed phases due to the additions of aluminium dross as filler.

\section{References}

Adeosun, S. O., Usman, M. A., Ayoola, W. A., \& Sekunowo, I. O. (2012). Evaluation of the Mechanical Properties of Polypropylene-Aluminum-Dross Composite. ISRN Polymer Science, 2012, 282515. http://dx.doi.org/10.5402/2012/282515

Ayman, A. A., El-Shafei, B. Z., AbdAllah, A. A., Aly, A. E., \& Wahid, A. W. (2012). Friction and Wear of Polymer Composites Filled by Nano-Particles": A Review. World Journal of Nano Science and Engineering, 2, 32-39. http://dx.doi.org/10.4236/wjnse.2012.21006

Brunner, A. J., Necola, A., Rees, M., Gasser Ph., Kornmann, X., Thomann, R., \& Barbezat, M. (2006). The influence of silicate-based nano-filler on the fracture toughness of epoxy resin. Engineering Fracture Mechanics, 73, 2336-2345. http://dx.doi.org/10.1016/j.engfracmech.2006.05.004

Bum-Soon, L., Jack, L. F., John, R. C., \& Jerry, D. A. (2002). Effect of filler fraction and filler surface treatment 
on wear of microfilled composites. Dental Materials, 18(1), 1-11.

Kanchanomai, C., Noraphaiphipaksa, N., \& Mutoh, Y. (2011). Wear characteristic of epoxy resin filled with crushed-silica particles. Composites: Part B, 42, 1446-1452.

Kang, Y. K., Chen, X. H., Song, S. Y., Yu, L. G., \& Zhang, P. Y. (2012). Friction and wear behavior of nanosilica-filled epoxy resin composite coatings. Applied Surface Science, 258(17), 6384-6390. http://dx.doi.org/10.1016/j.apsusc.2012.03.046

Kuan, C. F., Chen, W. J., Li, Y. L., Chen, C. H., Kuan, H. C., \& Chiang, C. L. (2010). Flame retardance and stability of carbon nanotube epoxy composite prepared from sol-gel method. J. Phys. Chem. Solids, 71(4), 539-543. http://dx.doi.org/10.1016/j.jpcs.2009.12.031

Liang, J. Z., Li, R. K. Y., \& Tjong, S. C. (1997). Tensile fracture behaviour and morphological analysis of glass bead filled low density polyethylene composites. Plast. Rubber Compos. Process Appl., 278-282.

Milad, Z., Mehrzad, M., Babak, S., \& Jam, J. E. (2013). Fracture toughness of epoxy polymer modified with nanosilica particles: Particle size effect. Engineering Fracture Mechanics, 97, 193-206. http://dx.doi.org/10.1016/j.engfracmech.2012.10.027

Miller, A. G. (2007). The Boeing 787 Dreamliner., Keynote Address, $48^{\text {th }}$ AIAA/ASME/ASCE/AHS/ASC Structures, Structural Dynamics, and Materials Conference, Waikiki, HI.

Reddy, C. S., \& Das, C. K. (2006). Polypropylene-nanosilica-filled composites: Effects of epoxy-resin-grafted nanosilica on the structural, thermal, and dynamic mechanical properties. Journal of Applied Polymer Science, 102(3), 2117-2124. http://dx.doi.org/10.1002/app.24131

Rosso, P., Ye, L., Friedrich, K., \& Sprenger, S. (2006). A toughened epoxy resin by silica nanoparticle

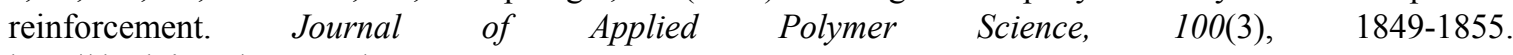
http://dx.doi.org/10.1002/app.22805

Ruban, Y. J. V., Mon, S. G., \& Roy, D. V. (2013). Mechanical and thermal studies of unsaturated polyester-toughened epoxy composites filled with amine-functionalized nanosilica. Applied Nanoscience, 3(1), 7-12. http://dx.doi.org/10.1007/s13204-012-0068-x

Stickler, P. B. (2002). Composite Materials for Commercial Transport. Issues and future research directions. Proceedings of the ASC, 17th Annual Technical Conference, West Lafayette, IN.

Tarrío-Saavedra, J., López-Beceiro, J., Naya, S., \& Artiaga, R. (2008). Effect of silica content on thermal stability of fumed silica/epoxy composites. Polym. Degrad. Stab., 93(12), 2133-2137.

Tjong, S. C., \& Xu, S. A. (2001). Ternary polymer composites: PA6,6/maleated SEBS/glass beads. J. Appl. Polym. Sci., 81, 3231-3237. http://dx.doi.org/10.1002/app.1777

Zhu, Z. K., Yang, Y., Yin, J., \& Qi, Z. N. (1999). Preparation and properties of organosoluble polyimide/silica hybrid materials by sol-gel process. J. Appl. Polym. Sci., 73, 2977-2984. http://dx.doi.org/10.1002/(SICI)1097-4628(19990929)73:14<2977::AID-APP22>3.0.CO;2-J

\section{Copyrights}

Copyright for this article is retained by the author(s), with first publication rights granted to the journal.

This is an open-access article distributed under the terms and conditions of the Creative Commons Attribution license (http://creativecommons.org/licenses/by/3.0/). 